\title{
ANALISIS STOK KARBON HUTAN MANGROVE PADA BERBAGAI TINGKAT KERUSAKAN DI SEGARA ANAKAN CILACAP
}

\author{
Mia Azizah ${ }^{1)^{*}}$, Erwin Riyanto Ardli $^{2)}$, Eming Sudiana ${ }^{2)}$ \\ ${ }^{1)}$ Program Studi Biologi FMIPA Universitas Nusa Bangsa Bogor \\ Jl. KH Soleh Iskandar KM 4 Cimanggu Tanah Sareal, Bogor 16166 \\ ${ }^{2)}$ Fakultas Biologi Universitas Jenderal Soedirman, Purwokerto \\ *email : mia.azizah90@yahoo.com
}

\section{ABSTRACT \\ Cabrbon Stock Analysis of Mangrove Forest in Every Damaged Level in Segara Anakan Cilacap}

\begin{abstract}
Mangrove is a specific vegetation type, found in tropical and subtropical beach area which located in Cilacap at a sloping beach area near the mouth of a river and the beach protected from the waves. Segara anakan is one of mangroves region which located at $108^{\circ} 46^{\prime}-109^{\circ} 03{ }^{\prime} E$ and $07^{\circ} 34^{\prime}-07^{\circ} 47^{\prime}$ 'South Latitude. Human activities series in Segara anakan mangrove lead the damage of this region, it affects to the ecological and biological or mangrove function as carbon storage place. The aims of this research was to analyze the damage level of mangrove in Segara anakan, Cilacap; to know the spatial distribution of mangrove damage level in Segara anakan; analyze the amount of biomass and carbon stocks at various of damage level in Segara anakan, and to know the number corelation of carbon stocks with damage level in Segara anakan, Cilacap.The research used survey method with purposive random sampling that determine the sampling location based on the damage level. Damage analysis used assessment teristis method (field survey) and than spasial distribution used surfer 9.0 and ArcView GIS 3.2. Biomass analysis and the amount of carbon stock used descriptive methods, damage level correlation and the amount of carbon stock used Pearson correlation analysis (SPSS software vs. 19).The result was Segara anakan mangrove, Cilacap currently was divided into not damage (7 station), damaged (3 station) and heavily damaged (5 station) categories. The amount of biomass and carbon stocks in not damaged area (57,67 tons/ha and 26,50 tons/ha); damaged area $(23,40$ tons/ha and 10,74 tons/ha, and the heavily damaged area $(9,49$ tons/ha and 4,37 tons/ha). The destruction of mangrove forest affected the amount of biomass and carbon stocks in Segara anakan, Cilacap.
\end{abstract}

Keywords : mangrove, carbon stock, damage level, Segara Anakan Cilacap

\begin{abstract}
ABSTRAK
Hutan mangrove merupakan tipe vegetasi khas, terdapat di daerah pantai tropis dan subtropis yang tumbuh subur di daerah pantai yang landai di dekat muara sungai dan pantai yang terlindung dari hempasan gelombang. Segara Anakan adalah salah satu kawasan hutan mangrove yang terletak pada koordinat $07^{\circ} 34^{\prime}-07^{\circ} 47^{\prime}$ LS dan $108^{\circ} 46^{\prime}-109^{\circ} 03^{\prime}$ BT. Serangkaian aktivitas manusia di kawasan hutan mangrove Segara Anakan menyebabkan kawasan ini mengalami kerusakan, hal tersebut berpengaruh terhadap fungsi ekologis dan biologis serta fungsi hutan mangrove sebagai penyimpan karbon. Penelitian ini bertujuan untuk menganalisis dan mengetahui tingkat kerusakan hutan mangrove di Segara Anakan Cilacap; mengetahui distribusi spasial potensi stok karbon hutan mangrove di Segara Anakan Cilacap dan mengetahui korelasi jumlah stok karbon dengan tingkat kerusakan di Segara Anakan Cilacap.Penelitian ini menggunakan metode survei dengan menggunakan teknik purposive random sampling yaitu menentukan lokasi sampling berdasarkan pada tingkat kerusakan. Analisis kerusakan menggunakan metode penilaian teristis (survey lapangan) yang selanjutnya didistribusi spasial menggunakan surfer 9.0 dan Arcview GIS 3.2. Analisis biomassa dan jumlah stok karbon menggunakan metode deskriptif, korelasi tingkat kerusakan, dan jumlah stok karbon menggunakan analisis korelasi Pearson (Software SPSS vs. 19). Hasil yang diperoleh adalah hutan mangrove Segara Anakan Cilacap saat ini terbagi menjadi area dengan kategori tidak rusak (7 stasiun), rusak ( 3 stasiun) dan rusak berat (5 stasiun). Jumlah biomassa dan stok karbon di area yang tidak mengalami kerusakan (57,67 ton/ha dan 26,50 ton/ha), area yang rusak (23,40 ton/ha dan 10,74 ton/ha, dan area yang rusak berat $(9,49$ ton/ha dan 4,37 ton/ha). Kerusakan hutan mangrove berpengaruh terhadap jumlah biomassa dan stok karbon di Segara Anakan.
\end{abstract}




\section{PENDAHULUAN}

Hutan mangrove merupakan tipe tumbuhan yang terdapat di daerah pantai tropis dan subtropis.Mangrove umumnya tumbuh subur di daerah pantai yang landai di dekat muara sungai dan pantai yang terlindung dari hempasan gelombang, serta dapat hidup pada habitat dengan salinitas dan substrat yang cocok (Lakitan, 1993). Hutan mangrove memiliki berbagai macam fungsi antara lain yaitu fungsi ekologis sebagai pelindung garis pantai, mencegah intrusi air laut, habitat (tempat tinggal), tempat mencari makan, tempat asuhan dan pembesaran, tempat pemijahan bagi aneka biota perairan (Bismarket al, 2008). Hutan mangrove memiliki fungsi lain yaitu dapat mengurangi gas $\mathrm{CO}_{2}$ di atmosfer melalui proses fotosintesis dan apabila dibandingkan dengan kebanyakan hutan tropis, hutan mangrove memiliki kemampuan menyimpankarbon lebih banyak (Dahuri, 2003). Secara global diperkirakan hutan mangrove dapat menyerap $\mathrm{CO}_{2}$ dari atmosfer sebesar 25,5 juta ton/tahun (Ong et al., 2004).

Hutan mangrove memiliki potensi untuk dapat menyimpan karbon, mengurangi pemanasan global yang diakibatkan oleh Gas Rumah Kaca (Hairiah dan Rahayu, 2007). Akibat efek rumah kaca yang ditimbulkan menyebabkan fungsi ekologi akan berubah yang disebabkan oleh peningkatan panas global. Namun informasi mengenai seberapa besar kemampuan hutan mangrove dapat menyimpan karbon sampai saat ini masih terbatas.

Luas total hutan mangrove di Indonesia menurut Dahuri (2003)pada tahun 1996 adalah 3,5 juta ha. Tahun 2005 luas hutan mangrove indonesia hanya 2,9 juta ha (FAO, 2007). Hal ini menunjukkan bahwa luas hutan mangrove di Indonesia semakin lama semakin berkurang termasuk di Segara Anakan, Cilacap.Dari tahun 1978 sampai 1987 sekitar 3003,6 ha mangrove hilang, akan tetapi seluas 1741,1 ha mangrove baru terbentuk di area tanah timbul (Ardli dan Wolff, 2008).

Menurut Badan Pengelola Kawasan Segara Anakan (2003) pada tahun 2003, lebih dari $50 \%$ area mangrove di wilayah Segara Anakan mengalami kerusakan atau gangguan. Hal tersebut dikarenakan adanya beberapa faktor diantaranya yaitu sedimentasi, exploitasi sumberdaya yang tidak benar, konversi dan penebangan mangrove, migrasi penduduk serta faktor lain seperti belum terintegrasinya semua stakeholder dalam pengelolaan kawasan Segara Anakan (BPKSA, 2003; Ardli dan Wolff, 2009). Penurunan tersebut menyebabkan hutan mangrove Segara Anakan memiliki berbagai tingkat kerusakan, hal tersebut diduga akan berpengaruh terhadap fungsi hutan mangrove Segara Anakan sebagai penyimpanan karbon.

\section{BAHAN DAN METODA}

Materi yang digunakan dalam penelitian adalah hutan mangrove Segara Anakan, Cilacap (Gambar 1). Sedangkan alat yang digunakan adalah alat tulis,buku identifikasi (Kitamura et al., 1997 dan Giesen et al., 2006), GPS (Global Positioning System), perahu, tali rafia, meteran $1,5 \mathrm{~m}$, rol meter $100 \mathrm{~m}$, soil tester; thermometer; salt refraktometer, furnace, timbangan digital dan oven.

\section{Metode Penelitian}

Penelitian dilakukan dengan menggunakan metode survei. Penentuan stasiun dengan menggunakan Purposive Random Sampling yaitu menentukan lokasi pe-ngambilan sampel berdasarkan tingkat kerusakan ( hutan mangrove rusak, rusak berat dan rusak sedang) menurut Ardli et al. (2010). Pengambilan data mangrove dilakukan dengan menggunakan metode plot sampling (Mueller - Dumbois dan Ellenberg, 1974). Plot pengambilan sampel dilakukan pada berbagai tingkat kerusakan di Segara Anakan, Cilacap. 


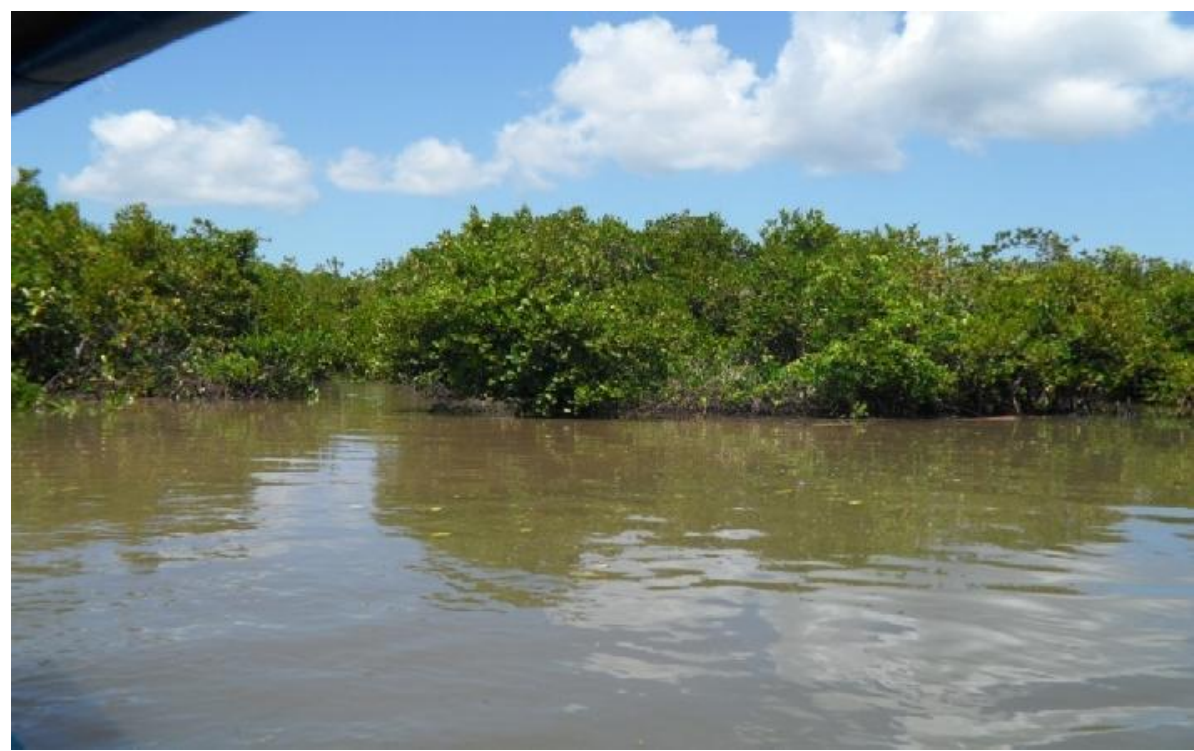

Gambar 1. Lokasi Penelitian Hutan Mangrove Segara Anakan, Cilacap

\section{Cara Kerja :}

Ukuran kuadrat yang digunakan untuk pengambilan data pohon adalah 10 x $10 \mathrm{~m}$, untuk anakan (sapling) adalah $5 \times 5 \mathrm{~m}$, dan semai $1 \times 1 \mathrm{~m}$. Pada setiap kuadrat diambil data mangrove baik data pohon maupun anakan pohonnya. Data pohon terdiri atas jumlah spesies, jumlah individu tiap spesies, diameter batang setinggi dada. Identifikasi mangrove dilakukan langsung di lapangan berdasarkan Kitamura et al.,1997 dan Giesen et al., 2006.

\section{Analisis Tingkat Kerusakan :}

Penentuan tingkat kerusakan mangrove di Segara Anakan, Cilacap didasarkan pada pedoman yang dikeluarkan oleh Dirjen Rehabilitasi Lahan dan Perhutanan Sosial (2005). Untuk menentukan tingkat kerusakan hutan mangrove pada masing-masing stasiun, diawali dengan menghitung total nilai skoring (TNS) yang didapatkan dengan model matematis, sebagai berikut :
TNS $=($ Tppl $\times 30)+(\mathbf{N} \times 25)+($ Np $\times 20)$ $+(\mathrm{L} \times 15)+(\mathrm{A} \times 10)$

Keterangan :

Tppl = Tipe Penutupan dan Penggunaan lahan

$\mathrm{N} \quad=$ Pohon

$\mathrm{Np} \quad=$ Permudaan

$\mathrm{L} \quad=$ Lebar jalur mangrove

A $\quad=$ Tingkat abrasi

Selanjutnya untuk mengetahui tingkat kerusakannya,

TNS yang diperoleh dari persamaan di atas dikelompokkan berdasarkan kriteria di bawah ini :

a. Nilai 100 - 200 : Rusak Berat

b. Nilai 201 - 300 : Rusak

c. Nilai> 300 : Tidak Rusak

\section{Distribusi Tingkat Kerusakan :}

Untuk mengetahui distribusi tingkat kerusakan data berdasarkan Dirjen Rehabilitasi Lahan dan Perhutanan Sosial (2005) akan dianalisis spasial dengan menggunakan program Surfer 9.0 dan ArcView GIS 3.2 (ESRI, 1990). Hasil analisis spasial dalam bentuk peta tematik kerusakan mangrove.

\section{Menghitung Kerapatan Mangrove}

Untuk mengetahui nilai kerapatan dari masing-masing tumbuhan mangrove pada setiap stasiun. Diperoleh dengan menggunakan rumus : 
Kerapatan $=\frac{\text { Jumlah individu suatu jenis }}{\text { Luas seluruh plot }}$

(Mueller-Dumbois dan Ellenberg, 1974)

\section{Biomasa dan Karbon Hutan Mangrove}

a. Menghitung Biomassa spesies Mangrove menggunakan Persamaan allometrik tersedia pada tabel 1 .

b. Karbon Hutan Mangrove

Perhitungan kandungan karbon hutan mangrove dilakukan dengan menggunakan rumus Kauffman et al. (2011) sebagai berikut :

\author{
Karbon $(C)=$ Biomassa $(B) x$ konversi \\ Tumbuhan : \\ Bruguiera gymnorhiza $\quad 0,46$ \\ Rhizophora apiculata $\quad 0,45$ \\ Sonneratia alba $\quad 0,47$ \\ Common equation $\quad 0,46$
}

untuk biomassa tiap spesies mangrove dan data karbon tersimpan yang diperoleh dari tiap stasiun pengambilan sampel dianalisis secara deskriptif.

\section{Analisis Korelasi}

Untuk mengetahui korelasi tingkat kerusakan dengan jumlah stok karbon dan kerapatan dengan jumlah stok karbon. Data akan dianalisis dengan menggunakan analisis korelasi Pearson (Software SPSS vs.19).

Tabel 1. Menghitung Biomassa spesies Mangrove menggunakan Persamaan allometrik

\begin{tabular}{|c|c|c|}
\hline No & Spesies & Persamaan allometrik \\
\hline 1 & Avicennia germinans & $\begin{array}{l}\text { Wtop }=(0.140) \mathrm{DBH}^{2.40} \text {, Fromard et al. } \\
(1998) \text { dalam Komiyama (2008) }\end{array}$ \\
\hline 2 & Avicennia marina & $\begin{array}{l}\text { Wtop }=0.1848 \mathrm{DBH}^{2.3524} \text {, Dharmawan dan } \\
\text { Siregar (2008) }\end{array}$ \\
\hline 3 & Bruguiera gymnorrhiza & Wtop $=0.186 \mathrm{DBH}^{2.31}$, Komiyama $(2008)$ \\
\hline 4 & Ceriops australis & $\begin{array}{l}\text { Wtop }=0.189 \mathrm{DBH}^{2.34} \text { Clough and Scott } \\
\text { (1989) dalam Komiyama (2008) }\end{array}$ \\
\hline 5 & Laguncularia racemosa & $\begin{array}{l}\text { Wtop }=0.102 \mathrm{DBH}^{2.50} \text { Fromard et al. } \\
\text { (1998) dalam } \\
\text { Komiyama (2008) }\end{array}$ \\
\hline 6 & Rhizophora apiculata & $\begin{array}{l}\text { Wtop }=0.235 \mathrm{DBH}^{2.42} \text {, Ong et al. (2004) } \\
\text { dalam } \\
\text { Komiyama (2008) }\end{array}$ \\
\hline 7 & $\begin{array}{l}\text { Rhizophora spp.(mangle } \\
\text { and racemosa) }\end{array}$ & $\begin{array}{l}\text { Wtop }=0.105 \mathrm{DBH}^{2.68} \text {, Clough and Scott } \\
(1989) \text { dalam Komiyama (2008) }\end{array}$ \\
\hline 8 & Xylocarpus granatum & $\begin{array}{l}\text { Wtop }=0.1832 \mathrm{DBH}^{2.21} \text {, Clough and Scott } \\
\text { (1989) dalam Komiyama (2008) }\end{array}$ \\
\hline 9 & Common equation & $\mathrm{W}=0.251 p \mathrm{D}^{2.46}$, Komiyama et al. $(2008)$ \\
\hline
\end{tabular}

Keterangan:

Wtop = Biomassa pohon/Berat kering $(\mathrm{kg})$

$\rho=$ Kerapatan kayu/Berat jenis kayu $\left(\mathrm{mg} \mathrm{m}^{-3}, \mathrm{~kg} \mathrm{dm}^{-3}\right.$ atau $\left.\mathrm{g} \mathrm{cm}^{-3}\right)$

$\mathrm{DBH}=$ Diameter batang setinggi dada $(\mathrm{cm})$ 
HASIL DAN PEMBAHASAN

\section{Tingkat Kerusakan dan Distribusi Kerusakan Hutan Mangrove Segara Anakan Cilacap}

\section{Total Nilai Skoring Kerusakan Hutan Mangrove Segara Anakan}

Analisis kerusakan hutan mangrove menggunakan metode penilaian secara langsung di lapangan (teristis) dengan parameter tipe penutupan dan penggunaan lahan, jumlah pohon per hektar (Kerapatan), jumlah permudaan (semai dan anakan pohon) per hektar, lebar jalur hijau mangrove dan tingkat abrasi (Dirjen Rehabilitasi Lahan dan Perhutanan Sosial, 2005).

Berdasarkan hasil penelitian tipe penutupan dan penggunaan lahan mangrove di Segara Anakan diklasifikasikan menjadi tiga kategori, yaitu: 1) hutan mangrove murni terdapat pada stasiun 1,2,3,4,5,7 dan 14 ; 2) hutan mangrove bercampur dengan area tambak terdapat pada stasiun $6,8,9,12,13$, dan $14 ; 3$ ) hutan mangrove bercampur dengan penggunaan lahan lain (pemukiman, tambak) pada stasiun 10,11 dan 15 .

Hasil penelitian menunjukkan dari kelima belas stasiun, hanya enam stasiun yang masih merupakan hutan mangrove murni. Menurut Ardli dan Wolff (2008) ekosistem mangrove Segara Anakan telah mengalami perubahan menjadi lahan budidaya akuakultur, pemukiman penduduk, penanaman tanaman antara selang tahun 1995 - 2004, dan sekitar 470 ha dikonversi menjadi tambak silvofishery. Selain menyebabkan tekanan yang sangat besar hal tersebut juga menyebabkan adanya perbedaan tipe penutupan dan penggunaan lahan di hutan mangrove Segara Anakan Cilacap.

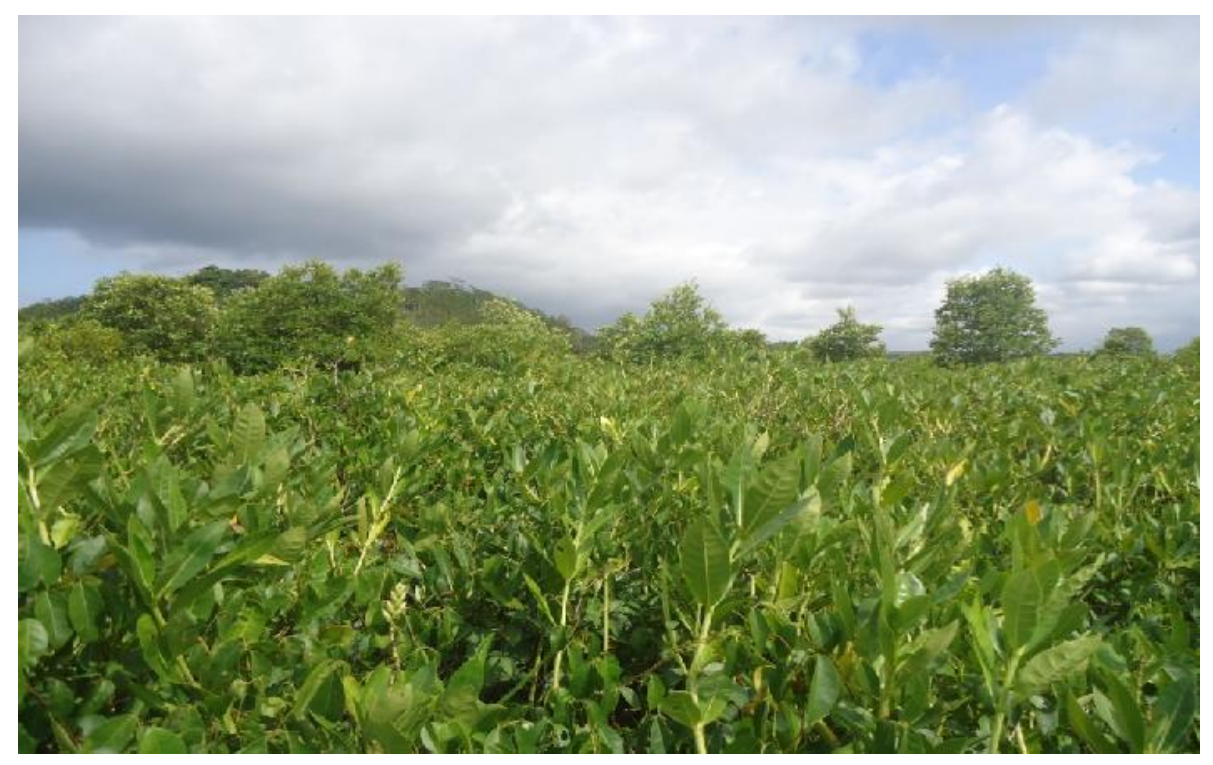

Gambar 2. Hutan Mangrove yang Mengalami Kerusakan 
Penentuan tingkat kerusakan mangrove didasarkan pada pedoman yang dikeluarkan oleh Direktorat Rehabilitasi dan Perhutanan Sosial (2005) dengan parameter, bobot dan skor tingkat kerusakan ekosistem mangrove. Hasil penelitian menunjukan ekosistem hutan mangrove Segara Anakan, Cilacap dapat dikategorikan kedalam kategori rusak berat, rusak dan tidak rusak seperti tertera pada tabel 2 .

Berdasarkan tabel 2 hasil perhitungan dari pedoman yang dikeluarkan Dirjen Rehabilitasi Lahan dan Perhutanan Sosial (2005), TNS > 300 termasuk kedalam kategori hutan mangrove tidak rusak, terdapat pada stasiun 1,2,3,4,5,7 dan 14 dengan nilai tertinggi sebesar 400. Hasil perhitungan paling besar didapat dari parameter tipe penggunaan dan penutupan lahan serta jumlah permudaan. Berdasarkan tipe penggunaan dan penutupan lahan, pada stasiun yang tidak mengalami kerusakan merupakan hutan mangrove murni dan terdapat jumlah permudaan (anakan pohon) sebesar $>2.500$ ind/ha. Hutan mangrove yang termasuk kedalam kategori rusak (Gambar 2) berada pada stasiun 9,10 dan 12 memiliki total nilai skoring sebesar 205, 235, 270 dengan jumlah nilai yang hampir sama dari setiap parameter kerusakan. Stasiun yang termasuk kedalam kategori rusak berat adalah stasiun $6,8,11,13$ dan 15 dengan TNS 170 - 200, hal tersebut disebabkan pada lokasi penelitian dengan kategori rusak berat merupakan hutan mangrove yang berdekatan dengan pemukiman atau areal tambak sehingga jumlah pohon dan anakan mangrove hanya sedikit.

Tabel 2. Total Nilai Skoring (TNS) Kerusakan Hutan Mangrove Segara Anakan

\begin{tabular}{rrrrrrrl}
\hline St. & TPPL & N & Np & L & A & Skoring & \multicolumn{1}{c}{ Tingkat } \\
\hline 1 & 150 & 25 & 100 & 75 & 50 & 400 & Tidak rusak \\
2 & 150 & 25 & 100 & 75 & 50 & 400 & Tidak rusak \\
3 & 150 & 25 & 100 & 75 & 50 & 400 & Tidak rusak \\
4 & 150 & 25 & 80 & 60 & 50 & 365 & Tidak rusak \\
5 & 150 & 25 & 80 & 60 & 50 & 365 & Tidak rusak \\
6 & 90 & 25 & 20 & 15 & 50 & 200 & Rusak berat \\
7 & 150 & 25 & 60 & 45 & 50 & 330 & Tidak rusak \\
8 & 90 & 25 & 20 & 15 & 50 & 200 & Rusak berat \\
9 & 90 & 25 & 60 & 45 & 50 & 270 & Rusak \\
10 & 60 & 25 & 40 & 30 & 50 & 205 & Rusak \\
11 & 60 & 25 & 20 & 15 & 50 & 170 & Rusak berat \\
12 & 90 & 25 & 40 & 30 & 50 & 235 & Rusak \\
13 & 90 & 25 & 20 & 15 & 50 & 200 & Rusak berat \\
14 & 90 & 25 & 100 & 75 & 50 & 340 & Tidak rusak \\
15 & 60 & 25 & 20 & 15 & 50 & 170 & Rusak berat \\
\hline
\end{tabular}




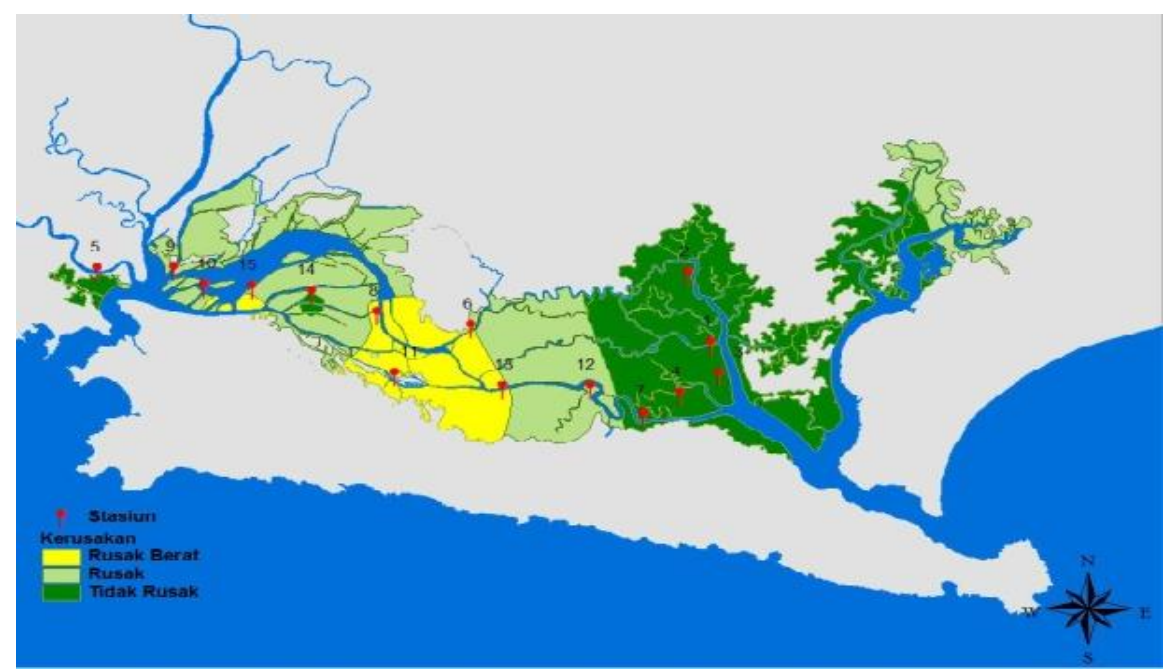

Gambar 3. Distribusi Kerusakan Hutan Mangrove Segara Anakan (2012)

\section{Tingkat Kerusakan Hutan Mangrove Segara Anakan}

Setelah didapatkan total nilai skoring (TNS) dari analisis kerusakan hutan mangrove berdasarkan survey lapangan, hasil distribusi spasial menggunakan Surfer 9.0 dan Arc View GIS 3.2 dapat dilihat pada gambar 1.Kondisi mangrove yang mengalami kerusakan serius (rusak berat) terjadi pada stasiun 6,8,11,13 dan 15 (Gambar1). Kerusakan serius terjadi pada area hutan mangrove yang terdapat jumlah individu pohon kurang dari 1000 ind/ha. Selain tidak adanya vegetasi mangrove kategori pohon, pada daerah yang mengalami kerusakan berat hanya ditemukan sedikit jumlah anakan pohon yaitu $0-160 \mathrm{ind} / \mathrm{ha}$ (< $1000 \mathrm{ind} / \mathrm{ha})$, dengan adanya kerapatan anakan pohon yang rendah akan berpengaruh terhadap lebar jalur hijau, karena untuk penentuan lebar jalur hijau di Segara Anakan didasarkan dari ditemukan vegetasi mangrove pada masing-masing stasiun (Onrizal, 2002). Berdasarkan tipe penggunaan dan penutupan lahan, hutan mangrove yang mengalami kerusakan terdapat pada area hutan mangrove yang berada dekat dengan pemukiman dan adanya daerah yang sudah dijadikan tambak, banyaknya illegal logging pada area ini menjadi tekanan yang sangat tinggi terhadap keberadaan hutan mangrove yang menurut Dahuri (2003) aktivitas manusia dapat menjadi sebab menurunnya biodiversitas dan komunitas mangrove.

Hasil distribusi pada peta tematik gambar 3, areal hutan mangrove yang termasuk kategori rusak berada di daerah tengah dan barat hutan mangrove Segara Anakan, stasiun yang mengalami rusak sedang yaitu stasiun 9,10, dan 12 . Dapat dilihat pada tabel 4.2 seluruh lokasi penelitian terdapat jumlah pohon $<1000 \mathrm{ind} / \mathrm{ha}$, jumlah anakan pohon (pancang) pada ketiga stasiun antara $1000-1700 \mathrm{ind} / \mathrm{ha}$. Kondisi tersebut sesuai dengan hasil penelitian Ardli et al. (2010) dimana daerah hutan mangrove Segara Anakan bagian tengah dan barat mendapat tekanan yang sangat besar dari sedimentasi, konversi lahan dan aktivitas manusia. Kondisi area hutan mangrove yang terjadi penebangan liar lebih terbuka dibandingkan dengan area yang tidak mengalami kerusakan, penutupan kanopi pohon pada hutan mangrove yang mengalami kerusakan tidak terlalu rapat sehingga cahaya matahari yang menembus hutan lebih besar dibandingkan dengan area mangrove yang tidak mengalami kerusakan yang penutupan kanopinya lebih rapat (Lakitan, 1993). 
Daerah hutan mangrove yang tidak mengalami kerusakan berdasarkan hasil analisis dan distribusi spasial terdapat pada stasiun 1, 2, 3, 4, 5, 7 dan 14 (gambar 1). Stasiun tersebut terdapat di Segara Anakan bagian timur, yang mendapat tekanan cukup besar dari industri (Ardli et al., 2010), kondisi hutan mangrove tersebut masuk kedalam kategori tidak rusak dengan jumlah anakan pohon yang paling tinggi yaitu $4150 \mathrm{ind} / \mathrm{ha}$ ( > $2.500 \mathrm{ind} / \mathrm{ha}$ ) karena masyarakat sekitar hutan mangrove lebih memanfaatkan kayu dari pohon mangrove yang sudah besar. Selain itu lokasi penelitian termasuk kedalam hutan mangrove murni (tidak ada tambak dan pemukiman) menjadikan daerah tersebut masih sedikit mendapat tekanan dari aktivitas manusia.Area hutan mangrove yang tidak mengalami kerusakan dapat menjadi data acuan sebagai usaha konservasi untuk menjaga ekosistem mangrove Segara Anakan, Cilacap.

\section{Jumlah Biomassa dan Stok Karbon Hutan Mangrove Segara Anakan}

\section{Jumlah Biomassa, Stok Karbon dan Dsitribusi Spasial Stok Karbon Hutan Mangrove Segara Anakan}

Tumbuhan mangrove melalui proses fotosintesis menyerap $\mathrm{CO}_{2}$ dari atmosfer, mengubahnya menjadi karbon organik dan menyimpannya dalam biomassa tubuhnya seperti dalam batang, daun, akar dan buah (Sutaryo, 2009). Menurut Kitamuraet al (1997) biomassa adalah total jumlah materi hidup di atas permukaan pada suatu pohon dan dinyatakan dengan satuan ton berat per satuan luas. Pengukuran biomassa hutan mangrove mencakup seluruh biomassa hidup yang ada di atas permukaan tanah, dan pada tingkat pohon dan pancang (anakan pohon) pengukuran biomasa menggunakan metode allometrik dan didasarkan pada pengukuran diameter batang (Hairiah dan Rahayu, 2007). Untuk perhitungan stok karbon di hutan mangrove diestimasi $0,46-0,50 \%$ dari jumlah biomasa (Kauffman et al, 2011).

Dapat dilihat pada tabel 3 hutan mangrove Segara Anakan memiliki biomassa sebesar 57,67 ton/ha pada daerah yang tidak mengalami kerusakan, 23,40 ton/ha terdapat pada daerah yang rusak dan 9,49 ton/ha pada daerah yang mengalami rusak berat. Sedangkan stok karbon yang disimpan pada berbagai tingkat kerusakan yaitu sebesar 26,50ton/ha pada daerah yang tidak rusak, 10,74 ton/ha pada daerah yang rusak dan 4,37 ton/ha stok karbon pada daerah yang mengalami rusak berat.

Tabel 3. Biomassa dan Stok Karbon (ton/ha)

\begin{tabular}{cccc}
\hline No & $\begin{array}{c}\text { Tingkat } \\
\text { Kerusakan }\end{array}$ & Biomassa (ton/ha) & $\begin{array}{c}\text { Stok karbon } \\
\text { (ton/ha) }\end{array}$ \\
\hline 1 & Tidak Rusak & 57,67 & 26,50 \\
2 & Rusak & 23,40 & 10,74 \\
3 & Rusak Berat & 9,49 & 4,37 \\
\hline
\end{tabular}




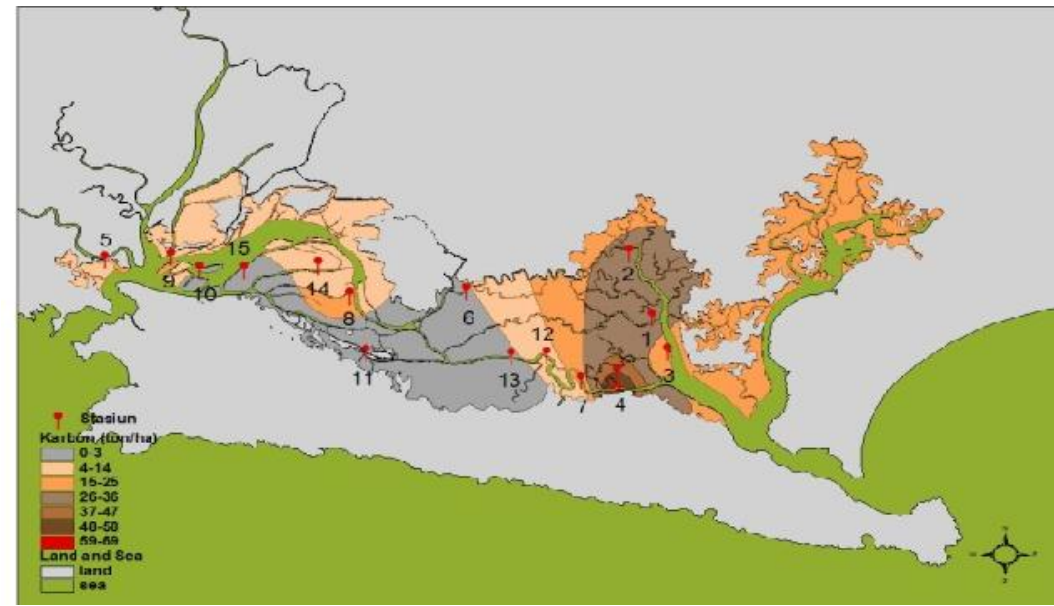

Gambar 4. Distribusi Stok Karbon Hutan Mangrove di Segara Anakan (2012)

Perbedaan jumlah biomasa dan stok karbon pada setiap tingkat kerusakan disebabkan karena adanya perbedaan kerapatan individu, menurut Onrizal et al.(2010) stok karbon pada suatu ekosistem dipengaruhi oleh jenis tumbuhannya. Suatu ekosistem yang terdiri dari pohon dengan spesies yang mempunyai nilai kerapatan pohon tinggi, biomassanya akan lebih tinggi bila dibandingkan dengan area yang mempunyai spesies dengan nilai kerapatan pohon rendah. Hal tersebut dapat dilihat pada gambar 4, tumbuhan mangrove dengan kerapatan tinggi terdapat pada stasiun 1,2,3 dan 4 yang terletak di wilayah timur, mampu menyimpan karbon lebih besar dibandingkan dengan stasiun yang ada di wilayah barat dan tengah Segara Anakan.

Hasil penelitian Murdiyarso et al. (2009) menyebutkan hutan mangrove di Segara Anakan mampu menyimpan karbon sebanyak 7,5 ton/ha sedangkan hasil penelitian Hilmi et al. (2003) hutan mangrove Segara Anakan memiliki stok karbon sebesar 90, 91 ton/ha. Hal tersebut disebabkan dalam selang waktu antara tahun 2003 - 2012 penyimpanan karbon Segara Anakan mengalami penurunan yang terjadi akibat adanya illegal logging, alih fungsi lahan dan aktivitas manusia (Ardli dan Wolf, 2009). Selain itu pada lokasi penelitian lebih banyak ditemukan pohon yang masih berada pada tingkat pancang, sehingga kemampuan menyimpan karbon lebih rendah dibandingkan pada tingkat pohon yang besar (mature) karena proporsi terbesar $(30-40 \%)$ stok karbon pada pohon dengan diameter besar (Sutaryo, 2009). Dan hasil penelitian menunjukan nilai stok karbon tidak mengalami penurunan yang terlalu jauh dari tahun ke tahun. Dengan mengetahui kemampuan hutan mangrove Segara Anakan dapat menyimpan karbon sebesar 26,50 ton/ha, dapat dijadikan acuan dalam pengelolaan hutan mangrove.

\section{Hubungan Stok Karbon dengan Kerapatan dan Tingkat Kerusakan Hutan Mangrove Segara Anakan}

Korelasi kerapatan dengan jumlah stok karbon terdapat nilai sebesar 0,751, berdasarkan data kerapatan didapatkan pada stasiun dengan kerapatan tinggi akan mempengaruhi jumlah stok karbon yang tersimpan, stasiun 2 memiliki kerapatan sebesar 4440 ind/ha, dan mampu menyimpan stok karbon 32,6 ton/ha hasil tersebut lebih tinggi dibandingkan dengan stasiun 13 dengan jumlah individu $160 \mathrm{ind} / \mathrm{ha}$ hanya mampu menyimpan karbon sebesar 1,04 ton/ha. Hal tersebut menunjukan semakin rapat dan semakin baik kondisi hutan mangrove maka akan semakin 
banyak karbon yang disimpan (Bismark et al, 2008).

Berdasarkan hasil analisis Pearson SPSS vs. 19 antara tingkat kerusakan dengan jumlah stok karbon menunjukkan nilai sebesar 0,657 , angka tersebut menunjukan adanya pengaruh cukup kuat antara keduanya. Pada stasiun yang tidak rusak (stasiun $1,2,3,4,5,7$ dan 14) terdapat pohon $A$. corniculatum sebanyak 231 ind/ha dan mampu menyimpan karbon lebih banyak $(12,57$ ton/ha) dibandingkan dengan stasiun yang mengalami kerusakan $(0,22$ ton/ha) dan rusak berat (1,38 ton/ha). Sesuai dengan hasil penelitian Bismark et al. (2008) stasiun yang memiliki kerapatan pohon $R$. apiculata lebih tinggi ( $80 \mathrm{ind} / \mathrm{ha}$ ), memiliki stok karbon paling tinggi $(45,47$ ton/ha $)$ dibandingkan stasiun lainnya yang jumlah kerapatan $R$. apiculata lebih sedikit.

\section{KESIMPULAN}

1. Hutan Mangrove Segara Anakan terbagi kedalam daerah Tidak Rusak, Rusak dan Rusak Berat

2. Hutan Mangrove Segara Anakan pada daerah yang tidak rusak mampu menyimpan karbon sebesar 26,5 ton/ha

\section{DAFTAR PUSTAKA}

Ardli, E.R. and M. Wolff. 2008. Quantifying Habitat and Resource Use Changes in the Segara Anakan Lagoon (Cilacap, Indonesia) Over the Past 25 Years $(1978$ - 2004). Asian Journal of Water, Environment and Pollution 5 (4) : 59 - 67.

Ardli, E.R., E. Yani and A. Widyastuti.2010. Penggunaan Achantus ilicifolius dan Derris trifoliata Lour Sebagai Agen Biomonitoring Kerusakan Mangrove Segara Anakan
Cilacap. Laporan Penelitian.

Fakultas Biologi Universitas

Jenderal Soedirman,

Purwokerto.

Bismark, M., E. Soebiandono, N.M. Heriyanto. 2008. Keragaman dan Potensi Jenis Serta Kandungan Karbon Hutan Mangrove di Sungai Subelen, Siberut, Sumatera Barat. Jurnal Penelitian Hutan dan Konservasi Alam 5 (3) : 297 306.

BPKSA (Badan Pengelola Kawasan Segara Anakan). 2003. Laporan pelaksanaan proyek konservasi dan pembangunan Segara Anakan. Lokakarya Status, Problem dan Potensi Sumberdaya Perairan dengan Acuan Segara Anakan dan Daerah Aliran Sungai Serayu, Purwokerto.

Brown, S. 1997. Estimating Biomass and Biomass Change of Tropical Forest.FAOForestry Paper 134.

Clough, B.F. and K. Scott.1989 Allometric relationships for estimating above-ground biomass in six mangrove species.Forest Ecology and Management27 : 117 - 127.

Dahuri, R. 2003. Keanekaragaman Hayati Laut. PT. Gramedia Pustaka Utama, Jakarta.

Dharmawan, I.W.S. dan C.A. Siregar.2008. Karbon Tanah dan Pendugaan Karbon Tegakan Avicennia marina (Forsk.)Vierh.di Ciasem, Purwakarta. Jurnal Penelitian Hutan dan Konservasi Alam 5 (4) : $317-328$. 
Direktorat Jenderal Rehabilitasi Lahan dan Perhutanan Sosial.2005. Pedoman Inventarisasi dan Identifikasi Lahan Kritis Mangrove. Departemen Kehutanan, Jakarta.

Environmental Systems Research Institute (ESRI). 1990. Understanding GIS, the ARC/INFO method. Environmental Systems Research Institute, Inc. Redlands.

FAO (Food and Agriculture Organization of The United Nations). 2007. The World's Mangrove 1980-2005. FAO Forestry paper 153 , Rome.

Giesen, W., S. Wullffraat, M. Zieren and L. Scholten. 2006. Mangrove Guide Book For Southeast Asia. FAO and Wetlands International, Bangkok.

Hairiah,K. dan S. Rahayu. 2007. Petunjuk Praktis Pengukuran Karbon Tersimpan di Berbagai Macam Penggunaan Lahan. World Agroforestry Centre. Bogor.

Hilmi, E., A.S. Siregar, N. Andriyani and A.D. Syakti. 2003. Rapid Estimation of The Biomass and Carbon Sequeatration Potency of Mangrove Vegetation in Segara Anakan Lagoon. Research Institute, Fisheries and Marine Science Department, University of Jenderal Soedirman, Purwokerto.
Kauffman, J.B., C. Heider, T.G. Cole, K.A. Dwire and D.C. Donato. 2011. Ecosystem Carbon Stocks of Micronesian Mangrove Forest. Wetlands 31 : 343 - 452 .

Kitamura, S., C. Anwar, A. Chaniago and S. Baba. 1997. Handbook of mangrove in Indonesia: Bali \& Lombok. International Society for Mangrove Ecosystem. Denpasar.

Komiyama, A., J.E. Ong and S. Poungparn. 2008. Allometry, biomass, and productivity of mangrove forest: A review. Aquatic botany89 : 128 -137.

Lakitan, B. 1993.Dasar-Dasar Fisiologi Tumbuhan. Raja Gravindo Persada, Jakarta.

Mueller - Dombois, D. and H. Ellenberg. 1974. Aims and Methods of Vegetation Ecology. John Wiley, London.

Murdiyarso, D., D. Donato., J.B. Kauffman., S. Kurnianto., M. Stidham and M. Kanninen. 2009. Carbon storage in mangrove and peatlands ecosysytem : A preliminary account from plots in Indonesia.Working Paper 48.Center for International Forestry Research. Bogor. 
Onrizal. 2002. Evaluasi Kerusakan Kawasan Mangrove dan Alternatif Rehabilitasinya di Jawa Barat dan Banten. Hasil Penelitian. Departemen Kehutanan Universitas Sumatera Utara, Medan.

Onrizal., E.A. Perbatakusuma dan N. Sulistiyono. 2010. Kandungan Karbon Rawa Singkil di Nanggroe Aceh Darussalam dan Potensi Pengembangan Jasa Lingkungan.Prosiding Seminar Nasional Hasil - hasil Penelitian Bidang Kehutanan dan Hasil Hutan : 136 - 154.

Ong, J.E., W.K. Gong, and C.H. Wong .2004.Allometry and partitioning of the mangrove, Rhizophora apiculata.Forest Ecology 188 : 395 - 408.

Sutaryo, D. 2009. Perhitungan Biomassa Sebuah pengantar untuk studi karbon dan perdagangan karbon. Wetlands International Indonesia Programme, Bogor. 